\title{
INFLUENCE OF INTRA-ABDOMINAL PRESSURE ON THE BASIC VITAL FUNCTIONS AND FINAL TREATMENT OUTCOME
}

\author{
Petar Svorcan ${ }^{1}$, Maja Stojanović ${ }^{2}$ Predrag Stevanović ${ }^{3}$, Aleksandar Karamarković ${ }^{4}$, \\ Radmilo Jankovićs and Nebojša Ladjević ${ }^{3}$
}

${ }^{1}$ Department of Gastroenterology and Hepatology, Medical Faculty, University of Belgrade;

${ }^{2}$ Department of Anesthesiology and Intensive Care, Zvezdara Clinical Center;

${ }^{3}$ Department of Anesthesiology and Intensive Care, Medical Faculty, University of Belgrade;

${ }^{4}$ Emergency Department, Clinical Center of Serbia, Medical Faculty, University of Belgrade, Belgrade;

${ }^{5}$ Department of Anesthesiology and Intensive Care, Medical Faculty, University of Niš, Niš, Serbia

SUMMARY - The purpose of the study was to point to the importance of measuring intra-abdominal pressure (IAP) and of early recognition of the consequences of increased IAP on basic vital functions. Measurement of IAP via urinary bladder was conducted every 12 hours in 70 surgical patients with acute abdominal syndromes not previously operated on. Based on the measured IAP values, all patients were divided into groups of patients with normal IAP values $(n=20)$ and patients with increased IAP values $(n=50)$. Vital functions and basic laboratory analysis were monitored and the values obtained were compared with IAP in both patient groups. A statistically significant difference was found in body weight, body mass index, urine output, creatinine, urea, heart rate, partial pressure of oxygen $\left(\mathrm{PaO}_{2}\right)$ and partial pressure of carbon dioxide $\left(\mathrm{PaCO}_{2}\right)$ between patients with normal and increased IAP values. The increase in IAP values was found to be associated with an increase in $\mathrm{PaCO}_{2}$, respiratory rate, peak inspiratory pressure, central venous pressure, heart rate, Acute Physiology, Age and Chronic Health Evaluation II score, mortality rate, creatinine and urea values, and number of days of treatment in the intensive care unit. At the same time, the values of $\mathrm{PaO}_{2}$, blood oxygen saturation, diuresis and abdominal perfusion pressure were declining. IAP measurement is an old, cost-effective, reliable technique that is easy to perform and should be applied in all high risk patients.

Key words: Critical illness; Intra-abdominal hypertension; Monitoring, physiologic; Compartment syndromes

\section{Introduction}

Intra-abdominal hypertension (IAH) and abdominal compartment syndrome (ACS), the pathophysiologic manifestations of elevated intra-abdominal pressure (IAP), are significant causes of morbidity and mortality in critically ill patients. The prevalence of

Correspondence to: Petar Svorcan, $M D, P h D$, Department of Gastroenterology and Hepatology, Zvezdara Clinical Center, Dimitrija Tucovića 161, 11050 Belgrade, Serbia

E-mail: svorcanp@open.telekom.rs

Received September 14, 2015, accepted April 4, 2016
$\mathrm{IAH}$ and ACS is difficult to determine as there are different ways of measuring and determining IAP limits for development of IAH and ACS. According to the definition of the World Society of the Abdominal Compartment Syndrome (WSACS) ${ }^{1}$, the mean IAP was $10 \pm 4.8 \mathrm{~mm} \mathrm{Hg}$ in a mixed population of critically ill patients. Based on this study, normal IAP was present in $67.9 \%$, IAH (with mean IAP $15.8 \pm 3.4 \mathrm{~mm} \mathrm{Hg}$ ) in $32.1 \%$ and ACS in $4.2 \%$ of patients on admission. The prevalence of ACS among patients with IAH was $12.9 \%$. In patients with IAH, the case-fatality rate was $38.8 \% \%^{2-5}$. The case-fatality rate among patients with 
ACS was $45.1 \%$, with a high correlation with the presence of comorbid factors ${ }^{4,6}$.

Serial IAP measurements are essential in order to establish accurate diagnosis and to assess the probability of final outcome in patients developing IAH and ACS. Intravesicular technique of measuring IAP is easy and should be monitored in all patients considered to be at risk of significant IAP elevation.

The purpose of the study was to point to the importance of measuring IAP and of early recognition of the consequences of increased IAP on basic vital functions.

\section{Subjects and Methods}

Current research was designed as a prospective cohort study conducted from January 1 to November 1 , 2013, at the Intensive Care Unit (ICU) of Zvezdara Clinical Center in Belgrade. A total of 70 surgical patients with acute abdominal syndromes (acute pancreatitis, peritonitis, ascites, gastroparesis, ileus, pseudoobstruction of colon, distended abdomen) not previously operated on were included in the study.

Diagnostic criteria for acute pancreatitis were defined as the onset of typical abdominal symptoms and at least 3-fold elevated serum amylase or lipase levels, or characteristic findings of acute pancreatitis on transabdominal ultrasonography or on contrast enhanced computed tomography (CECT) scan reserved for patients in whom the diagnosis was unclear. Ascites was diagnosed by ultrasound. The diagnosis of other conditions was based on clinical, laboratory and echo sonographic criteria. Exclusion criteria were hypothermia (temperature $<33{ }^{\circ} \mathrm{C}$ ), major burns, major trauma and peritoneal dialysis.

The IAH/ACS were defined according to the definitions of WSACS ${ }^{1,3}$. IAH is defined by sustained or repeated pathological elevation of IAP $\geq 12 \mathrm{~mm} \mathrm{Hg}$. ACS is defined as sustained IAP $>20 \mathrm{~mm} \mathrm{Hg}$ that is associated with a new organ dysfunction or failure, which was not previously present $t^{1,3}$. Based on these definitions, the study cohort were divided into two groups (group with normal IAP $(<12 \mathrm{~mm} \mathrm{Hg})$ and group with high IAP levels) and followed-up until discharge from the ICU.

The measurement of IAP was performed according to the WSACS ${ }^{1}$ recommendations. All patients had urinary catheter placed into the bladder, while the oth- er end was connected to a three-way stopcock to the urine bag and part of the hose from the infusion set was connected to a measuring ruler marked in $\mathrm{cm}$. While conducting the measurement, the urine bag was taken off, the hose of the infusion set was attached and through it $25 \mathrm{~mL}$ of sterile saline was injected into the empty urinary bladder, which was then pinched. The measurement was performed with the patient in horizontal position on the back, at the end of the expiratory flow 30-60 s after the injection solution. Zero point is at the level of middle axillary line at iliac crest. The values obtained were expressed in $\mathrm{mm} \mathrm{Hg}$ by using a correction factor $\left(1 \mathrm{~mm} \mathrm{Hg}=1.36 \mathrm{~cm} \mathrm{H}_{2} \mathrm{O}\right)$.

The values of IAP thus obtained were compared with the following variables: age, sex, weight, height, body mass index (BMI), systolic, diastolic and mean arterial pressure (MAP), heart rate, central venous pressure (CVP), respiratory rate, gas analysis, peak inspiratory pressure of patients on mechanical ventilation, diuresis, and blood urea and creatinine levels. In order to estimate the probability of death in all patients, the Acute Physiology, Age and Chronic Health Evaluation (APACHE) II score was determined, as well as the value of the abdominal perfusion pressure (APP) as an accurate indicator of visceral perfusion and resuscitation and evaluation of survival in cases of IAH. Measurements of IAP were performed every twelve hours until the patient's discharge from the ICU. While measuring IAP, other inspected variables were determined (systolic, diastolic and mean arterial pressure, heart rate, CVP, respiratory rate, gas analysis, peak inspiratory pressure, APP, and blood urea and creatinine levels), diuresis per hour was monitored and other inspected variables were determined upon patient admission to the ICU.

The study was approved by the local Medical Ethics Committee, and formal consent was obtained from the patients.

Numerical characteristics were described by the methods of descriptive statistics: mean and measures of variability (standard deviation), and minimum and maximum value. On analysis of the results, depending on the nature of data, Student's t-test was used to compare between-group differences in parametric data on particular parameter. On analysis of between-group differences in homogeneous or nonparametric data on particular parameter, we used Wilcoxon-Mann-Whitney rank sum test. On analysis of the bond strength 
between various parameters, depending on the nature of data, Pearson's correlation coefficient was used for homogeneous data and Spearman's correlation coefficient for non-homogeneous or nonparametric data. In all statistical methods employed, the level of significance was set at $\mathrm{p}<0.05$ and high level of statistical significance at $p<0.01$. Analysis of the survey data was performed by the Statistical Package for Social Sciences, version 19.0 for Windows (SPSS) (IBM, London, England).

\section{Results}

This study included 70 surgical patients with acute abdominal syndromes, not previously operated on. There were 20 patients with normal IAP and $50 \mathrm{pa}^{-}$ tients with elevated IAP. The mean IAP value was $8.9 \pm 2.67 \mathrm{~mm} \mathrm{Hg}$ in the group of patients with normal IAP and $18.1 \pm 4.50 \mathrm{~mm} \mathrm{Hg}$ in patients with IAH. The main characteristics of study patients are shown in Table 1.

With the increase in IAP, a statistically significant increase was recorded in pulse, respiratory rate and partial pressure of carbon dioxide $\left(\mathrm{PaCO}_{2}\right)$, while the association of IAP with partial pressure of oxygen $\left(\mathrm{PaO}_{2}\right)$ and blood oxygen saturation $\left(\mathrm{SpO}_{2}\right)$ was also highly statistically significant, but with the values of $\mathrm{PaO}_{2}$ and $\mathrm{SpO}_{2}$ decreasing with the increase in IAP. In patients on mechanical ventilation $(n=19 ; 27 \%)$, the increase in IAP led to increase in the peak inspiratory pressure. Also, there was high statistical correlation between IAP increase and increase in the values of creatinine, urea, CVP and APACHE II score, while the increase in IAP caused a decrease in diuresis (Table 2).

Analysis of the APP revealed minimum values in patients with the highest values of IAP; these patients had the least amount of excreted urine and minimum values of the MAP, APP and filtration gradient (FG) in relation to other patients (Table 3). Also, there was a statistically significant correlation between APP and the amount of excreted urine, which showed the amount of urine output to decrease with APP reduction $(\mathrm{r}=-0.491, \mathrm{p}=0.0001)$.

Analyzing the outcome of treatment, mortality rate was $15 \%$ in the group of patients with normal IAP, whereas in the group of patients with IAP $>12 \mathrm{~mm} \mathrm{Hg}$ mortality rate was more than twice as high, i.e. $36 \%$. There was a statistically significant correlation between IAP increase and patient death $(\mathrm{r}=0.391, \mathrm{p}=0.001)$.

Table 1. Anthropometric and clinical parameters of patients with normal intra-abdominal pressure and those with intra-abdominal hypertension

\begin{tabular}{|c|c|c|c|c|}
\hline $\begin{array}{l}\text { Anthropometric } \\
\text { and clinical parameter }\end{array}$ & All patients & $\begin{array}{c}\text { Patients with } \\
\text { normal IAP }\end{array}$ & Patients with IAH & $\mathrm{p}$ \\
\hline IAP, $\mathrm{mm} \mathrm{Hg}$ & $15.4 \pm 5.81$ & $8.9 \pm 2.67$ & $18.1 \pm 4.50$ & 0.01 \\
\hline Age, years & $65.5 \pm 13.93$ & $63.2 \pm 17.78$ & $66.5 \pm 13.51$ & 0.458 \\
\hline Gender, male:female (\%) & $65.71 \pm 34.29$ & $70.0: 30.0$ & $64.0: 36.0$ & \\
\hline Body weight $(\mathrm{kg})$ & $79.2 \pm 17.84$ & $73.3 \pm 10.92$ & $81.5 \pm 19.53$ & 0.082 \\
\hline $\operatorname{BMI}\left(\mathrm{kg} / \mathrm{m}^{2}\right)$ & $24.2 \pm 4.82$ & $23.7 \pm 2.71$ & $26.3 \pm 5.73$ & 0.058 \\
\hline Height $(\mathrm{cm})$ & $175.6 \pm 7.9$ & $175.5 \pm 7.68$ & $175.6 \pm 8.07$ & 0.928 \\
\hline Systolic blood pressure $(\mathrm{mm} \mathrm{Hg})$ & $128.4 \pm 25.5$ & $122.5 \pm 24.48$ & $130.7 \pm 25.83$ & 0.220 \\
\hline Diastolic blood pressure $(\mathrm{mm} \mathrm{Hg})$ & $75.8 \pm 15.82$ & $73.0 \pm 15.80$ & $77.0 \pm 15.83$ & 0.348 \\
\hline MAP $(\mathrm{mm} \mathrm{Hg})$ & $90.21 \pm 17.78$ & $88.2 \pm 16.74$ & $94.02 \pm 19.23$ & 0.01 \\
\hline Heart rate & $96.4 \pm 17.82$ & $98.5 \pm 9.07$ & $122.9 \pm 10.55$ & 0.0001 \\
\hline $\mathrm{PaCO}_{2}(\mathrm{~mm} \mathrm{Hg})$ & $36.3 \pm 6.89$ & $35.9 \pm 3.32$ & $45.9 \pm 4.78$ & 0.0001 \\
\hline Diuresis $(\mathrm{mL})$ & $80.7 \pm 59.76$ & $110 \pm 61.98$ & $69.0 \pm 55.22$ & 0.01 \\
\hline Urea $(\mathrm{mg} / \mathrm{dL})$ & $17.12 \pm 19.74$ & $21.52 \pm 31.61$ & $15.36 \pm 12.24$ & 0.0001 \\
\hline Creatinine $(\mu \mathrm{mol} / \mathrm{L})$ & $178.43 \pm 118.43$ & $163.4 \pm 103.96$ & $184.57 \pm 124.33$ & 0.0001 \\
\hline $\mathrm{PaO}_{2}(\mathrm{~mm} \mathrm{Hg})$ & $84.75 \pm 23.76$ & $103.07 \pm 22.38$ & $79.97 \pm 21.91$ & 0.001 \\
\hline
\end{tabular}

Data are expressed as mean $\pm \mathrm{SD} ; \mathrm{IAP}=$ intra-abdominal pressure; $\mathrm{IAH}=$ intra-abdominal hypertension; $\mathrm{BMI}=$ body mass index; $\mathrm{MAP}$ $=$ mean arterial pressure $\mathrm{PaCO}_{2}=$ partial pressure of carbon dioxide $\mathrm{PaO}_{2}=$ partial pressure of oxygen 
Table 2. Effect of intra-abdominal pressure increase on test variables

\begin{tabular}{|l|c|c|}
\hline Test variable & $\mathrm{r}$ & $\mathrm{p}$ \\
\hline Heart rate & $0.761^{*}$ & 0.0001 \\
Respiratory rate & $0.332^{* *}$ & 0.005 \\
$\mathrm{PaCO}_{2}$ & $0.655^{*}$ & 0.0001 \\
$\mathrm{PaO}_{2}$ & $-0.388^{* *}$ & 0.003 \\
$\mathrm{SpO}_{2}$ & $-0.441^{*}$ & 0.0001 \\
Peak inspiratory pressure & $0.994^{*}$ & 0.0001 \\
Creatinine & $0.554^{*}$ & 0.0001 \\
Urea & $0.249^{*}$ & 0.038 \\
CVP & $0.631^{* *}$ & 0.0001 \\
Diuresis & $-0.444^{* *}$ & 0.0001 \\
APACHE II & $0.399^{*}$ & 0.004 \\
\hline
\end{tabular}

*Pearson's correlation coefficient; ${ }^{*}$ :Spearman's correlation coefficient; $\mathrm{p}=$ level of significance; $\mathrm{PaCO}_{2}=$ partial pressure of carbon dioxide; $\mathrm{PaO}_{2}=$ partial pressure of oxygen; $\mathrm{SpO}_{2}=$ blood oxygen saturation; $\mathrm{CVP}=$ central venous pressure; $\mathrm{APACHE} \mathrm{II} \mathrm{=} \mathrm{Acute}$ Physiology, Age and Chronic Health Evaluation II score

Table 3. Correlation of intra-abdominal pressure and mean arterial pressure with abdominal perfusion pressure, filtration gradient and diuresis

\begin{tabular}{|l|c|c|c|c|}
\hline \multirow{2}{*}{ Parameter } & \multicolumn{2}{|c|}{$\begin{array}{c}\text { Patients with } \\
\text { normal IAP }\end{array}$} & \multicolumn{2}{c|}{$\begin{array}{c}\text { Patients } \\
\text { with IAH }\end{array}$} \\
\cline { 2 - 5 } & $\mathrm{r}$ & $\mathrm{p}$ & $\mathrm{r}$ & $\mathrm{p}$ \\
\hline MAP $(\mathrm{mm} \mathrm{Hg})$ & -0.87 & 0.01 & -0.83 & 0.01 \\
APP $(\mathrm{mm} \mathrm{Hg})$ & -0.82 & 0.05 & -0.77 & 0.05 \\
FG $(\mathrm{mm} \mathrm{Hg})$ & -0.74 & 0.01 & -0.69 & 0.05 \\
Diuresis $(\mathrm{mL})$ & -0.68 & 0.01 & -0.54 & 0.01 \\
\hline
\end{tabular}

$\mathrm{r}=$ correlation coefficient; $\mathrm{p}=$ level of significance; IAP = intra-abdominal pressure; $\mathrm{IAH}=$ intra-abdominal hypertension; $\mathrm{MAP}=$ mean arterial pressure; $\mathrm{APP}=$ abdominal perfusion pressure; $\mathrm{FG}=$ filtration gradient

Deceased patients had a higher APACHE II score (30.6 \pm 9.24 vs. $28.2 \pm 7.56)$, but the difference was not significant, along with a statistically significantly higher rate of respiration $(r=0.455, p=0.0001)$, statistically significantly lower blood pressure (systolic $r=-0.273$, $\mathrm{p}=0.022)$, lower $\mathrm{SpO}_{2}(\mathrm{r}=-0.539, \mathrm{p}=0.0001)$, and they required mechanical ventilation support (11 of 19 mechanically ventilated patients). Increased values of IAP were associated with a statistically significant increase in the number of days spent at ICU $(r=0.236, p=0.49)$. Correlation with the number of days spent at ICU be- tween surviving patients with normal and surviving patients with increased IAP was also significant $(\mathrm{r}=0.23, \mathrm{p}=0.393)$.

\section{Discussion}

Until the WSACS conference, studies were conducted on a small number of patients or were of retrospective design, and thus did not provide correct information. At this conference, guidelines were adopted that have later been used in determining the value of IAP, and now we have accurate and reliable data. In an effort to show the impact of increased IAP on basic vital functions at ICU with less sophisticated equipment, we embarked upon analysis of the parameters of basic vital functions available at every ICU.

The parameters under study were compared with the mean values of IAP. The mean IAP value was $8.9 \pm 2.67 \mathrm{~mm} \mathrm{Hg}$ in patients that did not develop IAH and $18.1 \pm 4.50 \mathrm{~mm} \mathrm{Hg}$ in patients with IAH.

The two study groups differed significantly according to body weight and BMI, whilst age, gender and height did not show statistically significant difference. Patients with higher body weight and greater BMI had a higher risk of developing IAH. However, it was observed that patients with IAH were older than those with normal pressure, and were predominantly male. In the study by Sanchez et al. ${ }^{7}$, assessment of the parameters that could affect the increase in IAP revealed that the mean values of IAP were greater in men than in women, but without statistical significance. The same held for age and presence of comorbidities. Unlike these, BMI showed high statistical significance when both BMI and IAP were increased. Cobb et al. ${ }^{8}$ confirmed the results of previous studies.

Intra-abdominal pressure may influence hemodynamic pressures and thereby may affect organ perfusion, which manifests as disturbances of the cardiovascular, pulmonary and renal systems, and has an effect on hepatic, gastrointestinal and central nervous systems.

In the present study, it was observed that there was an increase in IAP and increase in MAP, but with the increase in IAP above $25 \mathrm{~mm} \mathrm{Hg}$ there was a fall in arterial pressure, and these patients eventually died. It was also shown that the increase in IAP caused tachycardia and higher values of CVP. Two experimental studies by Rosenthal et al. ${ }^{9}$ and Ben-Haim et al. ${ }^{10}$ 
showed the increase in IAP to be followed by an increase in systolic, diastolic and mean arterial pressure, as well as in CVP.

The study conducted by Yavuz et al. ${ }^{11}$, inducing IAH in experimental conditions of pneumoperitoneum, showed that an increase in IAP caused an increase in arterial blood pressure, $\mathrm{PaCO}_{2}$ and $\mathrm{PaO}_{2}$, whereas $\mathrm{SpO}_{2}$ remained unchanged. Also, in the study by Barnes et al. ${ }^{12}$ it was demonstrated that at very high levels of IAP there was an increase in blood pressure, whereas heart rate did not change, $\mathrm{PaO}_{2}$ decreased and $\mathrm{PaCO}_{2}$ increased. In contrast to these studies, the studies by Meininger et al. ${ }^{13}$ and Horvath et al..$^{14}$, which were also performed in experimental conditions, proved that there was only a minimal hemodynamic and metabolic change without statistical significance.

Gas analyses demonstrated a significant difference in the values of $\mathrm{PaO}_{2}$ and $\mathrm{PaCO}_{2}$ between the two groups. It was also shown that the increase in IAP increased $\mathrm{PaCO}_{2}$ values, while the values of $\mathrm{PaO}_{2}$ and $\mathrm{SpO}_{2}$ decreased. There was a significant difference between the patients with IAP $>12 \mathrm{~mm} \mathrm{Hg}$ and patients with normal IAP values. Patients with higher IAP values or a tendency of IAP rise became tachypneic, dyspneic, with reduced $\mathrm{SpO}_{2}$ and required mechanical ventilation support. If the IAP had an increasing trend or a high value from the beginning, and if the patients required mechanical ventilation support, then they had a high value of the peak inspiratory pressure and lower $\mathrm{SpO}_{2}$. Patients that were on mechanical ventilation had a higher mortality rate. Examining the issue of IAP, other researchers have reported similar chang$\mathrm{es}^{15,16,17}$, i.e. the increase in IAP caused an increase in respiratory rate, heart rate, $\mathrm{CVP}, \mathrm{PaCO}_{2}$, urea, serum creatinine and APACHE II score, while $\mathrm{PaO}_{2}, \mathrm{SpO}_{2}$, systolic and diastolic blood pressure, the amount of excreted urine, creatinine clearance, and mental status declined.

The present study demonstrated that there was a significant difference in the level of urea, creatinine and diuresis between the two study groups. Increase in the IAP led to increasing levels of urea and creatinine and decrease in diuresis and anuria in patients with IAP values $>25 \mathrm{~mm} \mathrm{Hg}$. By calculating the APP, which is an accurate indicator of visceral perfusion and restitution, it was proved that the reduction in MAP was accompanied by a decrease in APP and FG. An increase in the IAP and reduction of MAP and APP resulted in a decreased total urine output, which gradually led to anuria. In the group of patients with fatal outcome, an increase in IAP must have led to oliguria in case of constantly high IAP value, which rapidly led to anuria. Mullens et al. ${ }^{18}$ also showed that patients with IAH had higher creatinine values and lower FG values (56 vs. $65 \mathrm{~mm} \mathrm{Hg}, \mathrm{p}=0.03$ ). Sugrue et al. ${ }^{19}$ report on the correlation between IAH and renal function, for IAP values above $25 \mathrm{~mm} \mathrm{Hg}$. Renal dysfunction occurred within 2.7 days of IAP increase and the disorder developed gradually.

Mortality rate was $15 \%$ in patients with normal IAP values and $36 \%$ in patients with IAH. The rise in IAP was followed by increase in the number of deaths, these patients had higher APACHE II score, higher rate of respiration, lower blood pressure, lower $\mathrm{SpO}_{2}$, required mechanical ventilation support and were oliguric.

Increased IAP was associated with a higher number of days the patients spent in ICU. Patients with higher IAP values necessitated additional testing, medical treatment and care, thus increasing the number of staff members for these patients, prolonged treatment at ICU and additional costs. Studies conducted by Keskinen et al..$^{20}$ and Hong et al. ${ }^{21}$ also showed that the increase in IAP was followed by increase in the APACHE II score, lactate and creatinine levels, and number of days of ICU treatment. In these studies, the rise in IAP increased patient lethality from $10 \%$ to $50 \%$.

Efforts of the staff in every ICU should be channeled in such a manner that attention is in particular paid to the possible development of IAH in patients with acute abdominal syndromes, along with timely diagnosis and reduction of complications of this frequently overlooked disease.

\section{Conclusion}

In patients with acute abdominal syndrome, increased IAP is associated with increase in partial pressure of carbon dioxide, respiratory rate, peak inspiratory pressure, central venous pressure, heart rate, APACHE II score, mortality rate, creatinine and urea levels, and number of days of treatment in ICU, while the values of partial pressure of oxygen blood oxygen saturation, diuresis and abdominal perfusion pressure are declining. 


\section{References}

1. Malbrain MLNG, Cheatham ML, Kirkpatrick A, Sugrue M, Parr M, De Waele J, et al. Results from the International Conference of Experts on Intra-Abdominal Hypertension and Abdominal Compartment Syndrome. I. Definitions. Intensive Care Med. 2006;32:1722-32, http://dx.doi.org/10.1007/ s00134-006-0349-5.

2. Cheatham ML, Malbrain MLNG, Kirkpatrick A, Sugrue M, Parr M, De Waele J, et al. Results from the International Conference of Experts on Intra-Abdominal Hypertension and Abdominal Compartment Syndrome. II. Recommendations. Intensive Care Med. 2007;33:951-62, http://dx.doi.org/10.1007/ s00134-007-0592-4.

3. Kirkpatrick A, Roberts J, Waele J, Jaeschke R, Malbrain MLNG, De Keulenaer B, et al. Intra-abdominal hypertension and the abdominal compartment syndrome: updated consensus definitions and clinical practice guidelines from the World Society of the Abdominal Compartment Syndrome. Intensive Care Med. 2013;39:1190-206, http://dx.doi.org/10.1007/ s00134-013-2906-z.

4. Malbrain MLNG, Chiumello D, Pelosi P, Bihari D, Innes R, Ranieri M, et al. Incidence and prognosis of intraabdominal hypertension in a mixed population of critically ill patients: a multiple-center epidemiological study. Crit Care Med. 2005; 33:315-22, http://dx.doi.org/10.1097/01.CCM.00001153408. 09806.1B.

5. Malbrain MLNG, De Iaet I, Waele J. IAH/ACS: The rationale for surveillance. World J Surg. 2009;33:1110-5, http://dx.doi. org/10.1007/s00268-009-0039-x.

6. Kim B, Prowle J, Baldwin I, Bellomo R. Incidence, risk factors and outcome associations of intra-abdominal hypertension in critically ill patients. Anaesth Intensive Care. 2012;40:79-89.

7. Sanchez NC, Tenofsky PL, Dort JM, Shen LY, Helmer SD, Smith S. What is normal intra-abdominal pressure? Am Surg. 2001;67:243-8.

8. Cobb WS, Burns JM, Kercher KW, Matthews BD, Norton HJ, Heniford BT. Normal intraabdominal pressure in healthy adults.J Surg Res. 2005;129:231-5, http://dx.doi.org/10.1016/j. jss.2005.06.015.

9. Rosenthal RJ, Friedman RL, Chidambaram A, Khan AM, Martz J, Shi $Q_{2}$ et al. Effects of hyperventilation and hypoventilation on $\mathrm{PaCO}_{2}$ and intracranial pressure during acute elevations of intraabdominal pressure with $\mathrm{CO}_{2}$ pneumoperitoneum: large animal observations. J Am Coll Surg. 1998;187:32-8, http://dx.doi.org/10.1016/S1072-7515(98)00126-4.

10. Ben-Haim M, Mandeli J, Friedman RL, Rosenthal RJ. Mechanisms of systemic hypertension during acute elevation of intraabdominal pressure. J Surg Res. 2000;91:101-5, http:// dx.doi.org/10.1006/jsre.2000.5903.
11. Yavuz Y, Renning K, Lyng O, Marvik R, Grenbech JE. Effect of increased intraabdominal pressure on cardiac output and tissue blood flow assessed by color-labeled microspheres in the pig. Surg Endosc. 2001;15:149-55, http://dx.doi.org/10.1007/ s004640000336.

12. Barnes GE, Laine GA, Giam PY, Smith EE, Granger HJ. Cardiovascular responses to elevation of intra-abdominal hydrostatic pressure. Am J Physiol Regulatory Integrative Comp Physiol. 1985;248:208-13.

13. Meininger D, Byhahn C, Bueck M, Binder J, Kramer W, Kessler $\mathrm{P}$, et al. Effects of prolonged pneumoperitoneum on hemodynamics and acid-base balance during totally endoscopic robot-assisted radical prostatectomies. World J Surg. 2002; 26:1423-7, http://dx.doi.org/10.1007/s00268-002-6404-7.

14. Horvath KD, Whelan RL, Viscomi S, Barry L, Buck K, Bessler $\mathrm{M}$. The effects of elevated intrabdominal pressure, hypercarbia, and positioning on the hemodynamic responses to laparoscopic colectomy in pigs. Surg Endosc. 1998;12:107-14, http:// dx.doi.org/10.1007/s004649900608.

15. Parsak CK, Seydaoglu G, Sakman G, Acarturk TO, Karakoc E, Hanta I, et al. Abdominal compartment syndrome: Current problems and new strategies. World J Surg. 2008;32:13-9, http://dx.doi.org/10.1007/s00268-007-9286-x.

16. Moore AFK, Hargest R, Martin M, Delicata RJ. Intra-abdominal hypertension and the abdominal compartment syndrome. Br J Surg. 2004;91:1102-10.

17. Pilat J, Dabrowski W, Biernacka J, Bicki J, Rudzki S. Changes in intra-abdominal, iliac venous and central venous pressure in patients undergoing abdominal surgery due to large tumors of the colon-a pilot study. Acta Clin Croat. 2010;49:381-8.

18. Mullens W, Abrahams Z, Skouri HN, Francis GS, Taylor DO, Starling RC, et al. Elevated intra-abdominal pressure in acute decompensated heart failure: a potential contributor to worsening renal function? J Am Coll Cardiol. 2008;51:300-6, http:// dx.doi.org/10.1016/j.jacc.2007.09.043.

19. Sugrue M, Jones F, Deane SA, Bishop G, Bauman A, Hillman $\mathrm{K}$. Intra-abdominal hypertension is an independent cause of postoperative renal impairment. Arch Surg. 1999;134:1082-5, http://dx.doi.org/10.1001/archsurg.134.10.1082.

20. Keskinen P, Leppaniemi A, Pettila V, Piilonen A, Kemppainen E, Hynninen M. Intraabdominal pressure in severe acute pancreatitis. World J Emerg Surg. 2007;2:2, http://dx.doi.org/ 10.1186/1749-7922-2-2.

21. Hong JJ, Cohn SM, Perez JM, Dolich MO, Brown M, McKenney MG. Prospective study of the incidence and outcome of intra-abdominal hypertension and the abdominal compartment syndrome. Br J Surg. 2002;89:591-6. 


\section{Sažetak}

\section{UTJECAJ INTRAABDOMINALNOG TLAKA NA OSNOVNE VITALNE FUNKCIJE I ISHOD LIJEČENJA}

\section{P. Svorcan, M. Stojanovic, P. Stevanović, A. Karamarkovic, R. Janković i N. Ladjević}

Cilj studije bio je ukazati na značenje mjerenja intraabdominalnog tlaka (intra-abdominal pressure, IAP) i ranog prepoznavanja promjena osnovnih vitalnih funkcija, koje su posljedica povećanja IAP. Mjerenje IAP je provedeno kroz mokraćni mjehur svakih 12 sati kod 70 bolesnika s akutnim abdominalnim sindromom koji nisu prethodno operirani. Na osnovi izmjerenih vrijednosti IAP bolesnici su podijeljeni u skupinu s normalnim vrijednostima IAP $(n=20)$ i skupinu s povećanim vrijednostima $(n=50)$. Praćenjem osnovnih vitalnih funkcija i laboratorijskih analiza dobivene vrijednosti uspoređivane su u odnosu na IAP u objema skupinama bolesnika. Statistički značajna razlika između bolesnika s normalnim i onih s povišenim IAP utvrđena je za tjelesnu težinu, indeks tjelesne mase, diurezu, vrijednosti kreatinina, ureju, srčanu frekvenciju, parcijalni tlak kisika $\left(\mathrm{PaO}_{2}\right)$ i parcijalni tlak ugljičnog dioksida $\left(\mathrm{PaCO}_{2}\right)$. Također je zapaženo da su s porastom IAP rasle i vrijednosti $\mathrm{PaCO}_{2}$, broja respiracija, vršnog inspiracijskog tlaka, centralnog venskog tlaka, srčane frekvencije, akutna fiziološka, starosna i kronična evaluacija zdravlja II (Acute Physiology, Age and Chronic Health Evaluation, APACHE), stopa smrtnosti, vrijednosti ureje i kreatinina te broj dana liječenja u jedinici intenzivnog liječenja, dok su vrijednosti $\mathrm{PaO}_{2}$, zasićenje hemoglobina kisikom, diureza i abdominalni perfuzijski tlak bili u opadanju. Mjerenje intraabdominalnog tlaka je stara, jeftina, pouzdana metoda, jednostavna za izvođenje kod svih visoko rizičnih bolesnika.

Ključne riječi: Kritična bolest; Intraabdominalna bipertenzija; Monitoring, fiziološki; Sindromi kompartmenta 